\title{
QAWAID FIQHIYYAH DALAM FATWA MAJELIS ULAMA INDONESIA
}

\author{
Heri Firmansyah \\ Dosen Fakultas Syariah dan Hukum UIN Sumatera Utara \\ herifirmansyah@uinsu.ac.id
}

\begin{abstract}
In issuing its fatwa, the Indonesian ulema council uses a standardized method, which is always based on its decision based on strong foundations and arguments. The main sources of the MUI fatwa argument are the Koran and the Sunnah. the next sequence is the adillah alAhkam either agreed or not agreed upon by the mujtahid scholars, then qawaidh fiqhiyyah. Qawaidh fiqhiyyah is one of the important arguments for the Indonesian Ulema Council in issuing its fatwa. This article was written in the context of a survey of various types of qawaidh fiqhiyyah used by the MUI in issuing its fatwa. There are 4 fatwas surveyed which are about communication through social media, immunization, sharia electronic money (this fatwa was issued by the National Sharia council-MUI) and Organ and/or Body Tissue Transplantation from Dead Donors to Others. These fatwas were chosen because they contain various kinds of fiqhiyyah qawaidh and contain a minimum of 6 qawaidh fiqhiyyah.
\end{abstract}

Abstrak Di dalam mengeluarkan fatwanya, majelis ulama Indonesia menggunakan metode yang baku, yaitu senantiasa melandaskan keputusannya berdasarkan landasan dan dalil-dalil yang kuat. Sumber utama dalil fatwa MUI adalah Alquran dan Sunnah. urutan berikutnya adalah dalil-dalil hukum baik yang disepakati ataupun tidak disepakati oleh para ulama mujtahid, baru kemudian qawaidh fiqhiyyah. qawaidh fiqhiyyah adalah salah satu landasan dalil yang penting bagi Majelis Ulama Indonesia dalam mengeluarkan fatwanya. Artikel ini ditulis dalam rangka survey terhadap berbagai macam qawaidh fiqhiyyah yang dipergunakan MUI dalam mengeluarkan fatwanya. Ada 4 fatwa yang disurvey yaitu tentang bermuamalah melalui media sosial, imunisasi, uang elektronik syariah (fatwa ini dikeluarkan oleh dewan Syariah Nasional-MUI) dan Transplantasi Organ dan/atau Jaringan Tubuh Dari Pendonor Mati Untuk Orang Lain. fatwa-fatwa ini dipilih karena memuat berbagai macam qawaidh fiqhiyyah dan memuat minimal 6 kaidah fiqhiyyah.

Key Word : Qawaid Fiqhiyyah, Fatwa, Majelis Ulama Indone

\section{Pendahuluan}

Majelis Ulama Indonesia atau biasa disingkat MUI adalah Lembaga dan wadah untuk berkumpulnya ulama Indonesia dengan para cendekiawan muslim dan zu'ama (pemimpin) dalam memberikan pencerahan dan pelayanan kepada umat agar terjamin kehidupan bermasyarakat yang islami di Indonesia. Pendirian MUI bertujuan untuk menciptakan masyarakat yang berkualitas (khaira ummah), dan negara baik jasmaniah dan rohaniah, aman, adil damai dan yang diridhoi oleh Allah swt. (baldatun thayyibatun wa rabbun ghofur).

Salah satu fungsi lembaga MUI adalah sebagai lembaga pemberi fatwa bagi persoalan dan problematika yagn berkembang di tengah masyarakat yang 
yang berkaitan tentang hukum Islam, lewat komisi fatwanya. Terkadang fatwa-fatwa ini amat dibutuhkan untuk menyelesaikan problematika yang dihadapi oleh pemrintah dan umat Islam, baik diminta secara resmi ataupun inisiatif dari lembaga MUI. Artinya bisa saja sebelum persoalan tersebut disampaikan oleh masyarakat dan pemerintah, lembaga MUI telah secara responsif membahasa masalah yang berkembang di tengah masyarakat baik yang menjadi isu lokal maupun nasional. ${ }^{1}$

Makalah ini dibuat dalam rangka survey terhadap qawaid fiqhiyyah yang digunakan oleh MUI dalam mengeluarkan fatwanya. Sejauhmana MUI menggunakan qawaid fiqhiyyah dalam fatwa-fatwanya dan qawaid fiqhiyyah apa saja yang digunakan dari beberapa fatwa yang dikaji. Terlebih dahulu makalah ini menyajikan tentang profil lembaga MUI dan sistematika pengeluaran fatwa di MUI.

\section{Profil Majelis Ulama Indonesia}

Majelis Ulama Indonesia atau yang biasa disingkat dengan MUI berdiri pada tanggal 26 juli $1975 \mathrm{M}$, bertepatan dengan tanggal 17 Rajab 1395 H. Di dirikan di Jakarta dalam pertemuan para alim ulama, tokoh agama dan masyarakat serta kaum cendikiawan muslim Indonesia. Saat mula pendirian MUI, pertemuan dihadiri oleh para ulama utusan berbagai daerah provinsi, Pimpinan Organisasi kemasyarakat Islam, pembina kerohanian Angkatan Bersenjata Republik Indonesia (ABRI) dan beberapa

\footnotetext{
${ }^{1}$ Uraian di atas penulis intisarikan dari "Pedoman Dasar Majelis Ulama Indonesia hasil Musyawarah Nasional VII Tahun 2005", pada bagian Mukaddimah dan pasal 4,5 dan 6, Dikutip dari dokumentasi MUI, Rangkuman Hasil Keputusan MUSDA V Majelis Ulama Indonesia Sumatera Utara (Medan, 2001) h. 54-56.
}

undangan dari tokoh Islam yang hadir sebagai pribadi. ${ }^{2}$

MUI adalah organisasi keagamaan dan kemasyarakatan yang menjalankan organisasinya secara independen, artinya tidak terikat pada organisasi manapun dan tidak juga terikat pada partai politik, meskipun anggotanya adalah merupakan utusan dari berbagai kalangan dan lembaga. bermitra dengan pemerintah tanpa ada campur tangan antara satu dengan yang lainnya. MUI mendorong dan meyakinkan pemerintah bahwa kewajiban menegakkan amar ma'ruf dan nahi munkar, kebenaran dan keadilan adalah kewajiban bersama (fardhun jama'iy). Hal ini haruslah dilakukan dengan kolaborasi antara ulama, umara dan rakyat. Karena itu kepemimpinan umat Islam yang bersifat kolektif dan harmonisasi antara pemerintah dan ulama merupakan kewajiban (ijab al-ummah) dan keharusan yang harus diciptakan dalam rangka mewujudkan masyarakat yang agamis, adil, makmur dan sejahtera. $^{3}$

Tanda pembentukan MUI pusat diabadikan dengan penandatangan yang dilakukan oleh 53 orang ulama, terdiri dari 26 orang Ketua Majelis Ulama Provinsi seIndonesia (jadi sebelumnya telah dulu terbentuk MUI provinsi sebelum MUI Pusat), 4 orang ulama dari Dinas Rohani Angkatan Darat (AD), 10 orang ulama dari unsur ormas Islam tingkat Pusat, dan 13 orang ulama yang dianggap tokoh

${ }^{2}$ Dewan Pimpinan MUI Sumut, Profil Majelis Ulama Indonesia Pusat dan Sumatera Utara (Medan: t.p., 2006), h. 1.

3 Hal ini tercantum dalam "Muqaddimah Pedoman Dasar Majelis Ulama Indonesia", Dikutip dari Dewan Pimpinan MUI Medan, Dokumentasi MUI, Rangkuman Hasil Keputusan MUSDA V Majelis Ulama Indonesia Kota Medan, (Medan: t.p, 2001), h. $54-55$. 
berpengaruh yang diundang dan turut hadir sebagai pribadi. Sepuluh ulama dari organisasi Islam tingkat Pusat tersebut adalah H. Syafi'i Wirakusumah dari Syarikat Islam (SI), Ir. H. Basit Wahid dari Muhammadiyah, Anas Tanjung dari AlWashliyah, K.H. Moh. Dahlan dari Nahdhatul Ulama (NU), K.H. S. Qudratullah dari GUPPI H. Nurhasan Ibnu Hajar dari Perti, Zaenal Arifin Abbas dari AlIttihadiyah dan K.H Saleh Su'aidi dari Mathla'ul Anwar. ${ }^{4}$

Penandatanganan piagam ini terjadi pada tanggal 21-27 Juli 1975. Momen ini dianggap sebagai tanda berdirinya MUI Pusat dan muktamar nasional yang pertama. Sebelumnya, Pemerintah yang diwakili Departemen Agama membentuk panitia persiapan untuk membentuk majelis ulama tingkat nasional pada tanggal 1 Juli 1975, yang terdiri dari empat yaitu H. Sudirman, pensiunan jenderal Angkatan Darat sebagai ketua dan tiga orang ulama terkenal sebagai penasehat, yaitu: DR. Hamka, K.H. Abdullah Syafi'i dan K.H. Syukri Ghozali. Ketua Umum MUI yang pertama kali terpilih adalah DR. Hamka ${ }^{5}$ dengan Sekretaris Umumnya Kafrawi Ridwan. ${ }^{6}$

Sistem organisasi MUI sekarang memiliki empat tingkatan yaitu tingkat pusat hingga, tingkat I (propinsi), tingkat II (Kabupaten kota), dan tingkat kecamatan. Masing-masing berkedudukan di ibukota masing-masing. MUI Pusat berkedudukan di ibukota Negara Republik Indonesia yakni Jakarta. Kepengurusan MUI di tingkat nasional terdiri atas: Pelindung, yaitu Presiden RI, Dewan Pertimbangan yang

\footnotetext{
${ }^{4}$ Dewan Pimpinan, Profil Mejelis, h. 2.

${ }^{5}$ Seluk beluk terpilih dan kinerja Buya Hamka di MUI sebagai ketua Umum yang pertama dapat dibaca di Rusjdi Hamka, Pribadi dan Martabat Buya Hamka Prof. Dr. Hamka. Jakarta: Pustaka Panjimas, 1981.

${ }^{6}$ Dewan Pimpinan, Profil MUI, h. 2-4.
}

terdiri atas menteri yang memiliki hubungan tugas dengan pelaksanaan fungsi MUI dan para ulama terkemuka dalam masyarakat yang diketuai oleh Menteri Agama. Sedangkan Dewan Pimpinan sebagai pengelola kegiatan sehari-hari terdiri atas para ulama yang mencerminkan unsur-unsur yang terdapat dalam masyarakat. Dengan keikutsertaan berbagai unsur tersebut, MUI diharapkan dapat mampu berperan sebagai pemersatu bagi semua kelompok agama Islam. $^{7}$

Hubungan organisasi antara MUI Pusat dengan MUI daerah secara berjenjang bersifat koordinatif, aspiratif dan struktural administratif. Sedangkan hubungan antara MUI dengan organisasi kemasyarakatan/kelembagaan Islam bersifat konsultatif dan kemitraan. Ini menunjukkan bahwa MUI merupakan wadah musyawarah, bukan ormas. MUI tidak memiliki stelsel keanggotaan. MUI juga bukan merupakan federasi ormas-ormas atau kelembagaan Islam. $^{8}$

\section{Sistematika Pengeluaran Fatwa di MUI}

Telah menjadi sebuah kesadaran umum bahwa membiarkan persoalan yang dihadapi umat sehingga menjadikan mereka berada di dalam keadaan kebingungan tidak dapat dibenarkan secara syar'i. Oleh karena itu ulama diharapkan mampu memberikan jawaban dan kepastian hukum tentang ajaran Islam dari setiap persoalan yang dihadapi oleh umat Islam. MUI yang merupakan pengejewantahan dan perkumpulan ulama, zu'ama dan cendikiawan muslim Indonesia serta pengayom bagi seluruh masyarakat muslim Indonesia adalah lembaga yang diharapkan mampu untuk menjalankan

\footnotetext{
${ }^{7}$ Dewan Redaksi, Ensiklopedi Islam, Jild. 3 (Jakarta: PT. Ichtiar Baru van Hoeve, 2002), h. 123.

${ }^{8}$ Dewan Pimpinan, Profil Majelis, $h .5$.
} 
peran ini, memberikan jawaban dan solusi tepat atas setiap jawaban dan persoalan yang dihadapi umat Islam. Amanah yang diembankan ini, telah memberikan tanggung jawab besar kepada MUI untuk selalu memberikan fatwa yang dibutuhkan dan sesuai bagi setiap persoalan, dinamika dan perkembangan zaman. Dalam mengeluarkan fatwa, MUI membutuhkan berbagai metodologi yang menjadi acuan dasarnya. Metodologi ini dibuat guna menjamin fatwa yang dikeluarkan valid secara ilmiah dan sesuai dengan ajaran Islam.

MUI dalam mengeluarkan fatwanya juga memiliki pedoman tentang tata cara penetapan fatwa. Hal ini tertuang dalam pedoman penetapan fatwa Majelis Ulama Indonesia nomor U-596/MUI/X/1997 yang ditetatapkan pada tanggal 2 Oktober 1997 pada masa kepemimpinan K.H. Hasan Basri. $^{9}$ Adapun mengenai ketentuanketentuannya adalah sebagai berikut:

\section{Dasar-Dasar Umum Penetapan Fatwa}

MUI dalam pengambilan keputusan fatwanya memiliki dasar dan landasan dalil yang harus dipedomani. Ini dimaksudkan agar supaya fatwa yang dihasilkan dapat dipertanggungjawabkan dan sesuai dengan ajaran Islam. Adapun dasar-dasar umum bagi penetapan fatwa MUI terhadap suatu masalah adalah:

a. Setiap keputusan fatwa harus mempunyai dasar atas Kitabullah (Alquran) dan Sunnah Rasul yang mu'tabarah $^{10}, \quad$ serta tidak

9 Departemen Agama RI, Himpunan Fatwa Majelis Ulama Indonesia (Jakarta: 2003), h. 1-8.

${ }^{10}$ Istilah sunnah Rasul yang mu'tabarah dalam pedoman umum penetatapan fatwa MUI ini adalah sunah atau hadis yang tergolong dalam hadis sahih dan hasan yang dapat dijadikan sebagai hujjah atau landasan dalam penetapan hukum. Wawancara dengan Ramlan Yusuf Rangkuti selaku Ketua Komisi Fatwa MUI Sumatera Utara dan Ramli Abdul Wahid bertentangan dengan kemashlahatan umum.

b. Jika tidak terdapat dalam Kitabullah dan Sunnah Rasul sebagaimana ditentukan di atas, maka keputusan fatwa harus diambil dengan tidak bertentangan dengan Ijma', Qiyas yang Mu'tabar dan dalil-dalil hukum yang lain seperti: Istih\}san, Maslahah Mursalah dan Sadd azzari'ah.

c. Sebelum pengambilan keputusan fatwa, dianjurkan untuk mengkaji pendapat-pendapat para imam mazhab terdahulu, baik yang berhubungan dengan dalil-dalil hukum maupun yang berhubungan dengan dalil yang dipergunakan oleh pihak yang berbeda pendapat.

d. Pandangan tenaga ahli dalam bidang masalah yang akan diambil keputusan fatwanya haruslah dipertimbangkan.

\section{Prosedural Penetapan Fatwa ${ }^{11}$}

Adapun prosedur yang dilakukan MUI dalam setiap pengambilan keputusan atau penetapan fatwa adalah :

a. Setiap masalah yang disampaikan kepada Komisi hendaklah terlebih dahulu dipelajari dengan seksama oleh para anggota Komisi atau Tim Khusus sekurang-kurangnya seminggu sebelum disidangkan.

b. Mengenai masalah yang telah jelas hukumnya (qat'i) hendaklah Komisi menyampaikan sebagaimana adanya, dan fatwa menjadi gugur setelah

selaku Ketua Komisi Pendidikan dan Kebudayaan MUI Sumatera Utara pada tanggal 6 Juni 2009.

${ }^{11}$ Departemen Agama, Himpunan Fatwa, h. 5- 
diketahui ada nashnya dari Alquran dan Sunnah. ${ }^{12}$

c. Dalam masalah yang terjadi khilafiyyah di kalangan mazhab, maka yang difatwakan adalah hasil tarjih setelah memperhatikan fikih muqa>ran (perbandingan) dengan menggunakan kaidah-kaidah usul fikih muqara>n yang berhubungan dengan pentarjihan.

d. Setelah melakukan pembahasan secara mendalam komprehensif serta memperhatikan pendapat dan pandangan yang berkembang dalam sidang, Komisi menetapkan keputusan fatwa.

e. Setiap keputusan fatwa harus ditanfiz-kan setelah ditanda tangani oleh Dewan Pimpinan dalam bentuk Surat Keputusan Fatwa (SKF).

f. SKF harus dirumuskan dengan bahasa yang dapat dipahami dengan mudah oleh masyarakt luas.

g. Dalam SKF harus dicantumkan dasar-dasarnya disertai uraian dan analisis secara ringkas serta sumber pengambilannya.

h. Setiap SKF sedapat mungkin disertai dengan rumusan tindak lanjut dan/atau jalan keluar yang diperlukan sebagai konsekuensi dari SKF tersebut.

Jika kita menilik pada beberapa poin yang menjadi landasan metodologi di atas maka dapat kita pahami bahwa sumber utama MUI dalam pengambilan keputusannya adalah Alquran, Sunnah,

12 Ramli Abdul Wahid menjelaskan bahwa pernyataan ini bermakna jika terdapat kesalahan dalam pembuatan fatwa sehingga bertentangan dengan Alquran dan Sunah yang mu'tabarah, dikarenakan kekhilafan yang tidak disengaja atau kurangnya pengetahuan dari pengurus MUI khususnya di komisi fatwa, maka keputusan fatwa tersebut dapat dan harus dianulir.
Ijma' dan Qiya $>$ s al-Mu'tabar. ${ }^{13}$ Keempat hal ini merupakan sumber hukum Islam yang disepakati oleh ulama usul fikih (muttafaq alaiha). MUI juga mengakui berbagai sumber yang terdapat di dalamnya perbedaan pendapat di kalangan ulama (alMukhtalaf fiha) tentang dapat atau tidaknya metode tersebut dipergunakan dalam memutuskan hukum pada suatu masalah. Di antaranya yang disebutkan dalam keputusan MUI di atas adalah konsep Istih/san, maslahah dan sadd adz-zariah. Namun, MUI memakai semua konsep metode almukhtalaf fiha dalam pengistinbat\}an hukum terhadap suatu masalah yang akan difatwakan, sesuai dengan kebutuhan dan kemashlahatannya. $^{14}$

MUI juga mempertimbangkan dan bahkan mengkaji berbagai pendapat yang disampaikan oleh para imam mazhab terkemuka dalam satu persoalan hukum yang berkaitan dengan masalah yang akan difatwakan, baik dalil-dalil dan argumentasi yang mendukung maupun menentangnya untuk disimpulkan mana yang lebih kuat di antara keduanya (ditarjih).

\section{Penggunaan Qawaid Fiqhiyyah di Beberapa Fatwa MUI}

13 Qiya>s yang sesuai dan memenuhi rukun qiyas yang ditetapkan oleh ulama usul fikih. Wawancara dengan Ramlan Yusuf Rangkuti dan Ramli Abdul Wahid. Di antara persyaratan tersebut adalah: 1. Sesuai dengan ashal (pokok tempat untuk mengqiyaskan sesuatu), disebut juga al-Maqis a'laih; 2. Adanya hukum ashal ; 3. Adanya cabang (far'u); 4. Adanya 'illat, atau sebab adanya hukum. Lihat Satria Effendi M. Zein, Ushul Fiqh (Jakarta: Kencana, 2008), h. 132-135.

14 Wawancara dengan Darul Aman, Sekretaris Komisi Fatwa MUI Sumut pada tanggal 25 April 2009. 
Fatwa-fatwa yang dijadikan sampel dalam makalah ini diambil dari website resmi Majelis Ulama Indonesia di alamat www.mui.or.id. Sampel diambil dari empat fatwa MUI yang memenuhi standarisasi MUI dalam mengeluarkan putusan fatwa yang memuat empat bagian, yaitu menimbang, mengingat, memperhatikan dan menetapkan. Fatwa juga dipilih, setidaknya di dalamnya mengutip minimal enam kaidah fiqhiyyah sebagai landasan dalil dalam penetapan fatwa MUI.

Dalam konsideran Fatwa MUI, bagian fatwa yang memuat kaidah fiqhiyyah adalah pada bagian kedua dari konsideran fatwa yaitu di bagian "mengingat". Pertama sekali pada bagian ini diawali dengan landasan ayat Alquran. Kedua mengutip hadis Rasulullah saw. Ketiga, melandaskan pada metode istinbat\} hukum/adillah al-Ahkam baik yang disepakati ulama atau pun yang tidak disepakati ulama, yang merupakan objek kajian ushul fiqh. Keempat, mengutip kaidah-kaidah fiqhiyyah yang relevan dengan permasalahan yang akan dikeluarkan fatwanya. Jika poin ketiga tidak ada, maka kaidah fiqhiyyah menempati urutan yang ketiga. Adapun fatwa-fatwa yang terpilih menjadi sampel dalam makalah ini ada empat fatwa, sebagaimana penjelasannya berikut ini:

\section{Fatwa Majelis Ulama Indonesia nomor 24 Tahun 2017 tentang Bermuamalah melalui Media sosial}

Fatwa ini dikeluarkan MUI karena banyaknya berita hoax, pengumpatan, fitnah dan perbuatan buruk lainnya yang tersebar di berbagai media online utamanya di media sosial semacam facebook, instagram dan lainnya. Fatwa ini dimaksudkan sebagai panduan bagi umat Islam dalam menggunakan media sosial agar lebih santun, bijak dan terhindar dari dosa yang ditimbulkan dari penggunaannya.

Fatwa ini memuat enam kaidah fiqhiyyah. Adapun keenam Kaidah fiqhiyyah yang dikutip dalam fatwa ini adalah:

Pertama,

$$
\begin{aligned}
& \text { الأصل في المعاملات الإباحة إلا أن } \\
& \text { يدل دليل علي التحريم }
\end{aligned}
$$

"Pada dasarnya segala bentuk mu'amalah diperbolehkan kecuali ada dalil yang mengharamkannya atau meniadakan kebolehannya".

Kedua,

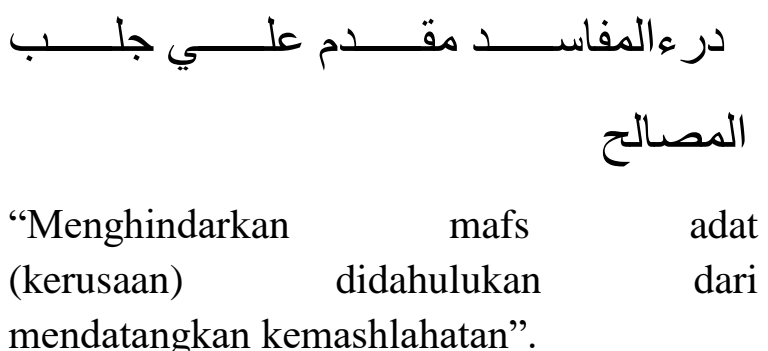

Ketiga,

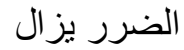

"Bahaya itu harus dihilangkan".

Keempat,

$$
\text { الكتاب كالخطاب }
$$

"Tulisan itu (memiliki kedudukan hukum) seperti ucapan".

\section{Kelima,}

$$
\text { لا عبرة للتو اهم }
$$


"Wahm ( hal yang masih hiprokit / samar/belum pasti) tidak bisa dijadikan pegangan".

Keenam,

$$
\text { تصرف الإمام على الرعية منوط بالمصلحة }
$$

Kebijakan seorang pemimpin atas rakyat harus berdasarkan kemashlahatan.

\section{Fatwa MUI Nomor 04 Tahun 2014} tentang Imunisasi.

Fatwa ini dikeluarkan MUI karena banyaknya penolakan sebagian masyarakat terhadap imunisasi yang merupakan program resmi dari pemerintah. Imunisasi adalah ikhtiar pemerintah dalam mencegah menyebarnya penyakit dan virus tertentu yang akan menghindarkan masyarakat untuk terkena penyakit berat dan menular. Imunisasi adalah tindakan preventif agar tidak terkena penyakit. Penolakan masyarakat baik didasarkan pada pemahaman agama bawah imunisasi mendahului takdir dan juga keraguan terhadap kehalalan dair vaksin yang digunakan.

Kaidah-kaidah fiqh yang digunakan di dalam fatwa ini adalah:

Pertama,

$$
\text { الأمر بالثيء أمر بوسائلة }
$$

"Perintah terhadap sesuatu berarti juga perintah bagi pelaksanaan prasarananya”. Kedua,

$$
\text { ما لا يتم الواجب الا به فهو واجب }
$$

"Suatu perbuatan yang apabila dengan perbuatan tersebut maka suatu perintah wajib menjadi sempurna, maka perbuatan tersebut hukumnya wajib”.

Ketiga,

$$
\text { الدفع أولي من الرفع }
$$

"Mencegah adalah hal yang lebih utama bila dibandingkan dengan menghilangkan (mengangkat/menyembuhkan)”.

Keempat,

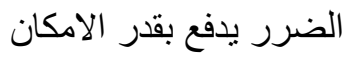

"d)arar (bahaya/kerugian) harus dapat dicegah dengan semaksimal mungkin”.

Kelima,

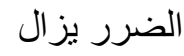

"segala d\}arar (bahaya/kerugian) harus dihilangkan".

Keenam,

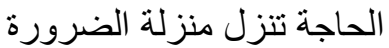

"Kondisi ha>jah (sudah menjadi sebuah kebutuhan), maka dia menempati kondisi yang darurat”.

Ketujuh,

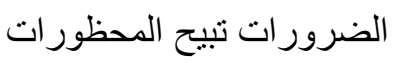

"Kondisi darurat maka menyebabkan dibolehkannysa sesuatu yang dilarang”.

Kedelapan,

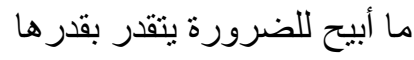

"Sesuatu yang dibolehkan karena dalam kondisi darurat, maka dibatasi sesuai dengan kadar atau kondisi kedaruratannya".

\section{Fatwa Dewan Syariah Nasional- MUI Nomor 116/DSN- MUI/IX/2017 tentang Uang Elektronik Syari'ah}


Fatwa ini berkaitan tentang uang elektronik yang berkembang di tengah masyarakat dalam berbagai transaksi, utamanya dalam transaksi jual beli online. Uang elektronik ini dikeluarkan oleh pihak Bank dan lembaga lain selain bank. Uang elektronik ini dipandang MUI perlu mendapatkan penjelasan hukum dari segi kesyari'ahannya. Karena itu yang dimaksudkan dengan uang elektronik syariah adalah uang elektronik yang sesuai dengan hukum Islam atau syariat Islam, sebagaimana ketentuan dan kriterianya dijelaskan dalam fatwa ini.

Adapun kaidah-kaidah fiqh yang dikutip dalam fatwa tentang uang elektronik syariah adalah sebagai berikut:

Pertama,

$$
\begin{aligned}
& \text { الأصـــل فــى المعـــاملات الإباحـــة إلا } \\
& \text { أن بدل دليل على التحريم }
\end{aligned}
$$

"Pada dasarnya segala bentuk mu'amalah diperbolehkan kecuali ada dalil yang mengharamkannya atau meniadakan kebolehannya”.

Kedua,

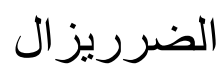

"segala d;arar (bahaya/kerugian) harus dihilangkan”.

Ketiga,

$$
\text { الضرر يدفع بقدر الإمكان }
$$

"d)arar (bahaya/kerugian) harus dapat dicegah dengan semaksimal mungkin”.

Keempat,

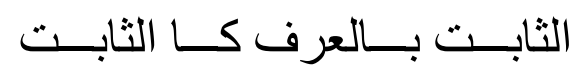

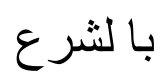

"Sesuatu yang berlaku berdasarkan pada u'rf (adat kebiasan) di tengah masyarakat sama dengan sesuatu yang berdasarkan syara'. (Selama tidak bertentangan dengan syariat)".

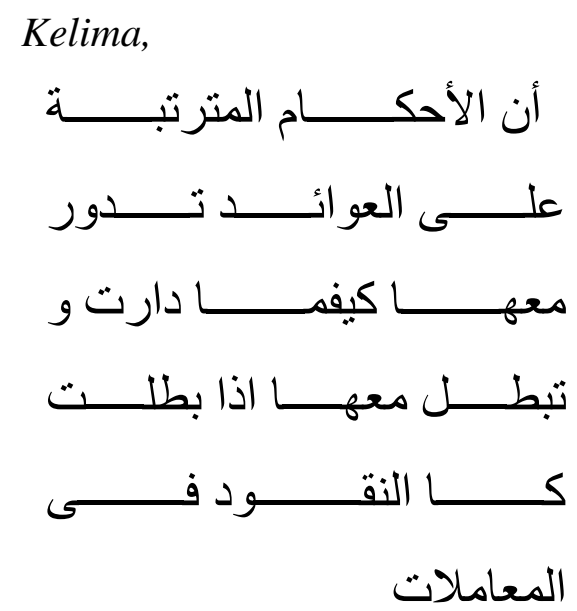

"Hukum yang berdasarkan pada adat (kebiasaan) berlaku bersama adat tersebut dan batal (tidak berlaku) bersamanya ketika ada itu batal, seperti mata uang dalam muamalat... (Al-Qarafi, Anwa $>$ r al-Buruq fi Anwa' al-Furuq, juz. 2 h. $228^{15}$ ).

Keenam,

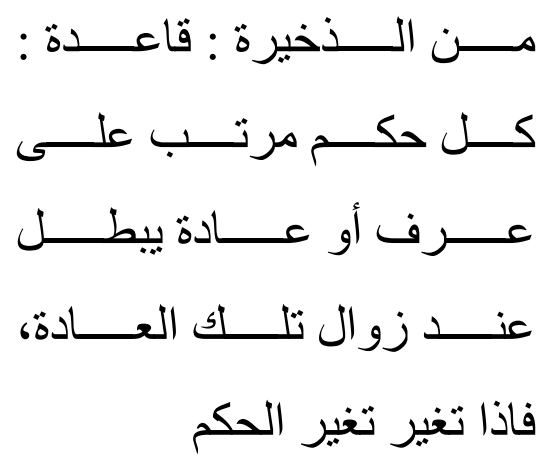

${ }^{15}$ Nama lengkap al-Qarafi, penulis buku yang dikutip untuk kaidah fiqhiyah ini yang digunakan dalam fatwa adalah Shihab al-Din Abu al-Abbas Ahmad ibn Idris al-Sanhaji al-Qarafi. Dia lahir di distrik Bahnasa, Mesir pada tahun 1228 Masehi. Beliau juga terkenal dengan penemuannya tentang teori pelangi dalam kitabnya al-Istibar fi $M a$ Tudrikuhu al-Abshar. Lihat di www.kanalkalimantan.com, dengan judul "Al-Qarafi, sang penemu Asli Teori Pelangi dari Mesir". Diakses tanggal 06-10-2019. 
"Dikutip dari kitab al-Z|akhirah", ada sebuah kaidah: setiap hukum yang didasarkan pada suatu 'urf (tradisi) atau adat (kebiasaan masyarakat) menjadi batal (tidak berlaku) ketika adat tersebut hilang. Oleh karena itu, jika adat berubah, maka hukum pun berubah". (at-Taj wa al-iklil liMukhtas\}ar Khalil, J.7. h. 68).

Ketujuh,

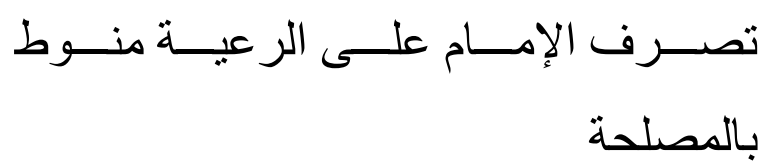

"Kebijakan seorang pemimpin atas rakyat harus berdasarkan kemashlahatan (bagi masyarakat)."

Kedelapan,

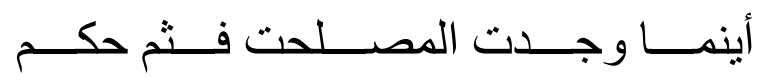

الله

"Dimana ditemukan kemashlahatan, maka disitu terdapat hukum Allah".

\section{Fatwa MUI nomor 12 Tahun 2019 Tentang Transplantasi Organ}

16 Tidak ada keterangan dalam fatwa siapa penulis dari kitab ini. Penulis berusaha untuk browsing di google dan menduga kitab yang dimaksud adalah kitab yang juga ditulis oleh Imam al-Qarafi, seperti kutipan kaidah fiqh yang di atasnya, seorang ulama dari Mazhab Maliki. Kitab az-Zakhira karangannya dianggap salah satu kitab terbaik dalam mazhab Maliki dan terkadang disebut sebagai ensiklopedi fiqh Maliki. Di dalam buku tersebut penulis juga memaparkan berbagai pendapat mazhab Imam Mazhab yang lain sehingga dapat juga dikategorikan sebagai kitab perbandingan mazhab (muqaran). Dapat dilihat di www.mustanir.net, dengan judul "mengenal kitab-kitab mazhab Maliki”, di akses tanggal 06 Oktober 2019. Dugaan ini menguat karena kaidah ini dikutip dari buku $a t-T a j$ wa al-iklil li-Mukhtasar Khalil yang ditulis oleh Abu Abd Allah Muhammad bin Yusuf bin Abi Mawwaq, yang juga bermazhab maliki.

\section{dan/atau Jaringan Tubuh Dari Pendonor Mati Untuk Orang Lain.}

Fatwa ini dikeluarkan berdasarkan dari pertanyaan tentang transplantasi organ atau jaringan tubuh orang lain kepada pasien yang membutuhkan, boleh atau tidak secara syariat hal tersebut dilakukan. Hal ini dikarenakan ada beberapa penyakit yang dapat disembuhkan dengan metode transplantasi atau metode pencangkokan organ atau jaringan tubuh orang lain kepada pasien yang membutuhkan. Fatwa ini permintaan resmi dari pemerintah diwakili oleh Kementerian Kesehatan kepada MUI untuk dikeluarkan fatwanya.

Adapun kaidah-kaidah fiqhiyyah yang dipergunakan sebagai landasan dalil dalam mengeluarkan fatwa ini adalah:

Pertama,

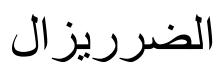

"segalad\}arar

(bahaya/kerugian/kemudaratan)harus

dihilangkan".

Kedua,

$$
\text { الضرر لايز ال بالضرر }
$$

"Kemudaratan tidak boleh dihilangkan dengan kemudaratan"

Ketiga,

$$
\text { الضرورات تبيح المحظور ات }
$$

"Kondisi darurat maka menyebabkan dibolehkannysa sesuatu yang dilarang”.

Keempat,

$$
\text { الضرر بدفع بقدر الإمكان }
$$

"d)arar (bahaya/kerugian) harus dapat

dicegah dengan semaksimal mungkin"

Kelima, 


$$
\text { المشقة تجلب التيسر }
$$

"Kesusahan/kesulitan akan

mendatangkan kemudahan"

Keenam,

لا يجوز الإنسان أن يتصرف فى حق لغير إلا بإذنه

"Tidak boleh mentasharufkan hak orang lain tanpa seizinnya".

Ketujuh,
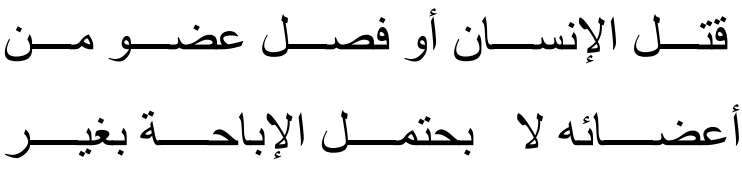

حق

"Membunuh manusia atau memotong organ tubuhnya tidak diperbolehkan kecuali ada kemashlahatan”.

Kedelapan,

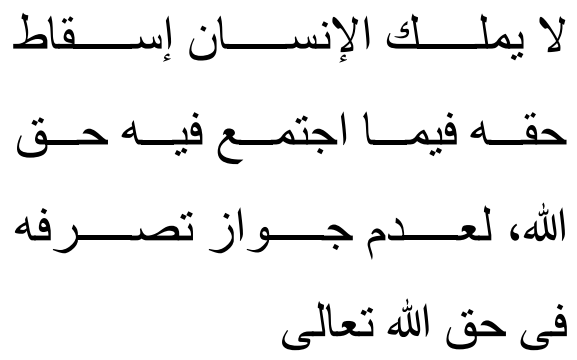

"Hamba tidak bias menggugurkan haknya dalam sesuatu yang bersamaan dengan hak yang dimiliki Allah, karena ketiadaan kebolehan mentasharufkan hak Allah".

Kesembilan,

$$
\text { قدم ماكان فيه حق الله وحق العبد على ماكان فيه حق العبد وحده }
$$

"Lebih didahulukan hak Allah dan hak hamba daripada haknya sendiri”.
Kesepuluh,
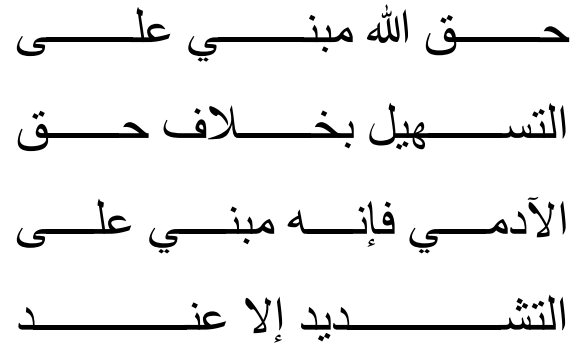

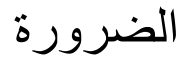

"Hak Allah itu bersifat lentur, berbeda dengan hak adami yang bersifat ketat (rigid, kaku), kecuali dalam keadaan darurat”.

Kesebelas,

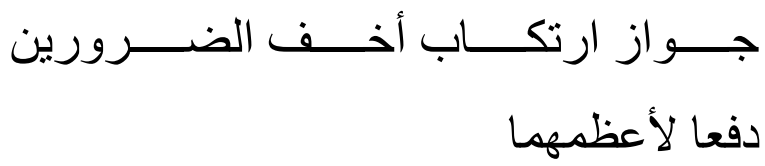

"Diperbolehkan mengambil darar yang lebih ringan, untuk menghindarkan darar yang lebih besar".

\section{Penutup}

Dari keempat contoh fatwa MUI yang dikemukan di atas, fatwa MUI telah dibuat dan dikeluarkan dengan tatacara yang baik dan baku. Fatwa-Fatwa MUI dalam konsiderannya, sebelum diakhiri dengan pengambilan dan kesimpulan hukum bagi sesuatu yang ingin difatwakan, maka akan mengutip dan menguraikan terlebih dahulu sumber dan landasan dalil-dalilnya serta berbagai hal yang berkaitan dengan fatwa semisal alasan fatwa dikeluarkan dan ketentuan umum yang memuat istilah-istilah yang terdapat di dalam kandungan fatwa dan lain sebagainya.

Kaidah fiqhiyyah adalah termasuk sumber penting bagi MUI dalam landasan hukum fatwa-fatwanya dalam periode kontemporer saat ini. Setidaknya setiap fatwa terkini, pasti akan memuat kaidah 
fiqhiyyah yang berkaitan dengan permasalahan yang diajukan dan diberikan keputusan fatwanya. Kaidah fiqhiyyah ini biasanya ditempatkan pada bagian keempat setelah Alquran, Sunnah dan metode istinbat hukum/adillah al-Ahkam yang menjadi bagian kajian ushul fikih, baik yang disepakati oleh para ulama yaitu seperti Ijma' dan Qiyas $\}$ maupun yang tidak disepakati seperti Sad az-Zari'ah (seperti contohnya pada fatwa hukum dan pedoman bermuamalah melalui media sosial). Jika metode istinbat \} hukum ini tidak ada maka kaidah fiqhiyyah menempati dasar landasan hukum yang ketiga bagi fatwa MUI seperti pada fatwa tentang imunisasi, uang elektronik syari'ah dan transplantasi organ tubuh.

\section{DAFTAR BACAAN}

Ambary, Hasan Muarif. Menemukan Peradaban, Jejak Arkeologis dan Historis Islam Indonesia. Jakarta: Logos, 1998.

Amin, Ma'ruf. "Kata Sambutan", Departemen Agama RI, Himpunan Fatwa Majelis Ulama Indonesia. Jakarta: t.p, 2003.

Dewan Pimpinan MUI Medan. Dokumentasi MUI, Rangkuman Hasil Keputusan MUSDA V Majelis Ulama Indonesia Kota Medan. Medan: t.p, 2001.

Dewan Pimpinan MUI Sumut, Profil Majelis Ulama Indonesia Pusat dan Sumatera Utara (Medan: t.p., 2006), h. 1.

Dewan Redaksi. Ensiklopedi Islam, Jild. 3. Jakarta: PT. Ichtiar Baru van Hoeve, 2002.

Hamka, Rusjdi Pribadi dan Martabat Buya Hamka Prof. Dr. Hamka. Jakarta: Pustaka Panjimas, 1981.
Indonesia, Majelis Ulama. Rangkuman Hasil Keputusan MUSDA V Majelis Ulama Indonesia Sumatera Utara. Medan: T.P, 2001.

Maarif, Ahmad Syafi'i. Studi Tentang Percaturan dalam Konstituante, Islam dan Masalah Kenegaraan. Jakarta: LP3ES, 1985.

RI, Departemen Agama. Himpunan Fatwa Majelis Ulama Indonesia. Jakarta: T.P. 2003.

Zein, Satria Effendi M. Ushul Fiqh. Jakarta: Kencana, 2008

\section{DAFTAR DOKUMEN}

1. Fatwa Majelis Ulama Indonesia Nomor 24 Tahun 2017 Tentang Hukum dan Pedoman Bermuamalah Melalui Media Sosial

2. Fatwa Majelis Ulama Indonesia Nomor 12 Tahun 2019 tentang Transplantasi Organ dan/atau Jaringan Tubuh dari Pendonor Mati Untuk Orang Lain.

3. Fatwa Majelis Ulama Indonesia Nomor 04 Tahun 2016 Tentang Imunisasi

4. Fatwa Dewan Syariah Nasional-Majelis Ulama Indonesia Nomor 116/DSNMUI/IX/2017 Tentang Uang Elektronik Syariah.

5. Pedoman Dasar Majelis Ulama Indonesia hasil Musyawarah Nasional VII Tahun 2005. 